\title{
EXPERIENCES WITH S170 TALL FESCUE
}

\author{
A. V. Allo and T. Southon \\ Farm Advisory Officer and Field Research Officer, \\ Department of Agriculture, Tauranga
}

Many hundreds of years ago, an old gentleman startled the inhabitants of the ancient city of Bagdad by offering to exchange new lamps for old ones. Today, a rather similar thing is happening on some New Zealand farms, where some farmers are replacing tall fescue with tall fescue.

What is this new type of tall fescue that is being publicized today? How does it differ from the weed grass that infests so much of our farmland? Why are some people advocating its use? Could I grow it on my farm? How do I grow it? How do I utilize it? These are some of the questions that have been asked the writers by farmers throughout the country over the past year or two. In this paper, an attempt will be made to answer them.

Tall fescue, Festuca arundirzacea, is a species of grass found in many parts of the world, and many ecotypes have evolved to suit varying conditions of climate and soil type. Basically, however, the species has certain characteristics. It is a perennial, deep-rooted plant, with a tall, tussocky growth habit. It is capable of growing on a wide range of soil types. The ecotype of tall fescue so familiar in this country is unpalatable to stock, of low nutritive value, and frequently has adverse effects on the health of cattle that graze it for prolonged periods.

There are, however, other strains of tall fescue which do not have these latter undesirable characteristics, and plant breeders both in New Zealand and overseas have been attempting to produce types of this plant that have the basic desirable characteristics plus palatability, higher quality, and freedom from toxic effects to stock. A number of strains of tall fescue have been produced by crossing and selection, and placed on the market. The type known as S170, bred at Aberystwyth in Wales, is the one with which this paper is concerned.

S170 tall fescue was bred from parent plants found in Northern Europe. It is very active in spring, summer and autumn. In England it is winter dormant, but, in many parts of New Zealand, it does produce some growth in the 
winter. It is capable of withstanding extremely harsh winter conditions. S170 will grow on a wide range of soil types, including reclaimed tidal flats. It is very drought resistant, and capable of producing herbage during dry periods when A riki ryegrass areas have dried up completely.

This fact showed up strikingly on a trial area near Te Puke, established March, 1964, during a period of hot, dry summer weather in 1965; On the area of $\mathbf{S 1 7 0}$ fescue, white clover and fescue were both green and vigorous, in marked contrast to the plots sown with 'Grasslands Ariki' ryegrass and white clover, on which both species were stunted and unproductive. An examination of the two treatments revealed that the roots of the fescue had penetrated the soil to a depth of over 12 in., whereas the roots of the A riki were only 3 in. deep.

S170 fescue, once established, appears to be compatible with most of the useful pasture plants, and it is also showing promise when sown with lucerne.

$\$ 170$, to be grown successfully, demands high soil fertility conditions. Adequate levels of nitrogen are essential. If soil fertility is low, production is limited and the herbage is of low palatability. It is essential that farmers fully appreciate this fact. It is useless trying to establish this grass on a very low fertility soil, and any farmer wishing to try this species is urged to sow it on one of his better paddocks.

The seed can be sown either in spring or autumn, but it must be sown into a cultivated seedbed. A ttempts have been made in the Bay of Plenty to underdrill fescue into existing pastures, both with and without chemical ploughing, but results have been disappointing.

When the writers first started work with 5170, they advocated sowing the seed broadcast, and harrowing it in. Establishment under this method of sowing was usually very slow, with little feed being produced off the new paddock until well on into the following spring. It has now been found that establishment is far quicker if the seed is sown through a drill or sodseeder into a cultivated seedbed, except on swamp country, where broadcasting-is still to be preferred.

It is recommended that the seed mixture be $18 \mathrm{lb}$ of $\mathrm{S} 170$ tall fescue plus $2 \mathrm{lb}$ white clover per acre. On reclaimed tidal flats, or under very wet conditions, the white clover could be partly replaced with strawberry clover. This simple mixture is suggested for a start, so that the fescue can become properly established. Later, there seems no reason why the paddock cannot be under-seeded with 
'Grasslands Ariki' or possibly 'Grasslands Paroa' ryegrass, or Western Wolths.

If a paddock is to be sown in a lucerne-tall fescue mixture, seeding rates of $18 \mathrm{lb}$ of fescue and $12 \mathrm{lb}$ of lucerne are suggested.

Over the past two seasons, some interesting data on the relative yields of $\mathrm{S} 170$ fescue and A riki ryegrass have been accumulated by the writers.

The period December-March, 1965-6, was fairly dry in the Paengaroa district in the Bay of Plenty in which a trial comparing Ariki ryegrass and S170 fescue had been sown the previous autumn. The soil is light volcanic ash, with good levels of phosphate and potash after many years of good farming. Over this four-month period, the $\$ 170$ fescue produced 4,000 lb of dry matter, as against the 2,300 lb produced by Ariki ryegrass. The fescue was fresh and leafy, and, from visual evidence, appeared to be just as digestible as the Ariki.

Further yield data were obtained from this trial during 1966 and 1967. During the period N ovember, 1965, to May, 1966, S170 tall fescue yielded 9,060 lb dry matter per acre, against a yield of 7,430 lb from Ariki ryegrass, an increase of $22 \%$.

During the 12-month period from June, 1966, to May, 1967, the fescue, with a per-acre dry matter yield of $14.180 \mathrm{lb}$, gave a $4.8 \%$ increase over Ariki which yielded $13,530 \mathrm{lb}$.

In any attempt to evaluate a grass, it is important to have knowledge as to the quality of the herbage. English experience indicates that S170 tall fescue has a high dry matter content, and that the percentage of crude protein is on a par with that in Italian ryegrass. The uptake of magnesium in the spring is higher than that of any of the ryegrass species, while the sugar content is also greater. Rogers (pers. comm.), of the Plant Breeding Institute at Cambridge, has established that S170 fescue, when conserved as hay, has a greater percentage of soluble carbohydrates than any other grass. In grazing trials in England, liveweight gains on areas of S170 fescue utilized as winter foggape are much superior to those obtained from areas of cocksfoot.

In New Zealand, chemical analyses were done in 1966 and early 1967 to determine if S170, under our conditions, has a greater content of magnesium than Ariki ryegrass. The results are shown in Table 1 . The figures were not 
TABLE 1: MAGNESIUM CONTENT OF S170 TALL HESCUE AND 'GRASSLANDS ARIKI' RYEGRASS

\begin{tabular}{|c|c|c|c|c|c|c|c|c|c|c|}
\hline & & & & & & & & & \multicolumn{2}{|c|}{ \% Magnesium } \\
\hline & & & & & & & & & $\$ 170$ & Ariki \\
\hline \multicolumn{11}{|l|}{1966} \\
\hline \multicolumn{2}{|c|}{ August } & 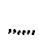 & & ...... & m... & $\ldots$ & $\ldots$ & ...... & 0.20 & 0.17 \\
\hline \multicolumn{2}{|c|}{ September } & & $\ldots . .$. & $\ldots$ & $\ldots$ & $\ldots$ & $\ldots$ & $\ldots$ & 0.18 & 0.16 \\
\hline October & $\ldots$ & & $\cdots$ & ..." & $\ldots$ & ..." & $\ldots$ & $\ldots$ & 0.23 & 0.22 \\
\hline \multicolumn{2}{|c|}{ November } & & $\ldots$ & ....... & 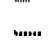 & ...... & ...... & ...... & 0.18 & 0.16 \\
\hline \multicolumn{11}{|l|}{1967} \\
\hline January & $\ldots$ & & ...."' & $\ldots$ & . & $\ldots$ & $\ldots$ & $\ldots$ & 0.27 & 0.24 \\
\hline February & $\ldots$ & & $\ldots$ & ..... & $\ldots$ & ..."' & ...... & $\ldots$ & 0.31 & 0.28 \\
\hline March & $\ldots$ & & $\ldots$ & ....... & $\ldots$ & $\ldots$ & ...." & $\ldots$ & 0.33 & 0.24 \\
\hline April & $\ldots$ & & $\ldots$ & $\ldots$ & $\ldots$ & $\ldots$ & $\ldots$ & $\ldots$ & 0.37 & 0.31 \\
\hline
\end{tabular}

subjected to statistical analysis. The object was merely to see how analyses from New Zealand material compared with those obtained by British workers.

Although the differences are not great, in the early spring the higher magnesium content of the $S 170$ may be of help in the avoidance of hypomagnesaemia. The value of this grass would be greatly increased if hay conserved from it were fed to cows over this period.

It has been found, both in trials and on farms where $\mathbf{S 1 7 0}$ is being grown, that $\mathrm{S} 170$ is very persistent provided soil fertility is satisfactory. It has stood up to both very wet and very dry conditions. It can be made into good hay or silage.

The real key to success with $\mathrm{S} 170$ tall fescue is to manage it properly. It must be kept well grazed, or it will give disappointing results. During the period October to A pril, it shows a quite remarkable recovery after being grazed, far greater than is the case with any of the ryegrass species, cocksfoot or paspalum. Farm management must be geared to make use of this rapid recovery growth. If a paddock of S170 is allowed to get too long before it is grazed, growth becomes unpalatable and stock will not do well on it. This introduces the factor of palatability. S170 will remain perfectly palatable provided it is grazed at a height of about 4 in., and has a satisfactory companion white clover growth.

If, for any reason, the fescue gets past 6 in., it should be kept closed for a cut of hay or silape. Indeed, English workers suggest that annual cutting of a fescue paddock improves the quality of the sward. 
In the writers' experience, it is not normal for a paddock of $\$ 170$ fescue to send up many seed heads. The exception was in the spring of 1966, after a long hard winter, when several areas of S170 sent up a number of seed heads. It was found that if this growth was topped at an early stage, no further attempt was made by the grass to go to seed, subsequent growth being leafy and very palatable.

The history of $\mathrm{New}$ Zealand agriculture contains many examples of stock health being adversely affected when cattle have been grazing on areas of the $\mathrm{New}$ Zealand ecotype fescue. There have been outbreaks of fescue poisoning, fescue foot, and so on. It would appear that S170 tall fescue has no adverse effects on stock health. All British authorities approached in 1964 stressed this point, and experience in the Bay of Plenty adds confirmation. The grass is quite harmless to stock.

One of the reasons the writers experimented with $\mathbf{S 1 7 0}$ was in the hope that stock could graze it without getting bloat. Evidence so far is rather conflicting. Areas sown down with red, as well as white, clover have produced bloat where the growth of clover has been strongly dominant, but, in other cases, areas of $\mathrm{S} 170$ and white clover have provided safe grazing, even in bloat-prone periods. More work is needed on this aspect.

In the autumn of 1966, a period when high counts of facial eczema spores were being recorded in the Tauranga County, a series of runs with the spore trap were made on three fescue-Ariki ryegrass trials. The results are given in Table 2.

In the third trial there was very little difference in spore numbers between S170 and Ariki. In this trial, the S170 had been badly burned by an application of fertilizer and

TABLE 2: FACIAL ECZEMA SPORE COUNTS ON S170 TALL FESCUE AND 'GRASSLANDS ARIKI' RYEGRASS TRIAL PLOTS

Count

\begin{tabular}{|c|c|c|c|c|c|c|c|}
\hline & & & & & & & Count \\
\hline \multicolumn{8}{|l|}{ Trial A } \\
\hline $\begin{array}{l}\text { \$170 (Plot 1) } \\
\text { S170 (Plot 2) } \\
\text { Ariki (Plot 1) } \\
\text { Ariki (Plot 2) }\end{array}$ & ."' & '"'"' & $\begin{array}{l}\cdot \\
\cdot \cdots+1 \\
\cdot \\
\cdots \cdots\end{array}$ & ."' & 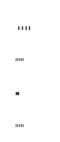 & $\begin{array}{l}\cdots+1 \\
\cdots \\
\cdot \\
\cdots\end{array}$ & $\begin{array}{c}47,500 \\
24,750 \\
100,000 \\
\text { Unreadably high }\end{array}$ \\
\hline \multicolumn{8}{|l|}{ Trial B } \\
\hline $\begin{array}{l}\text { Ariki } \\
\text { S170 }\end{array}$ & $\ldots$ & .' & 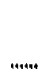 & $\ldots+\cdots$ & , "me' & $\cdots \cdots$ & $\begin{array}{c}\text { Unreadably high } \\
9,500\end{array}$ \\
\hline
\end{tabular}


had infinitely more litter than is normally found on areas of well-managed S170.

Spore trap runs in March, 1967, gave a similar picture with the S170 plots showing far fewer spores than the A riki ryegrass plots.

While, at this stage, it is not possible to assess the economic importance of this information, it does suggest that a well-managed sward of $\$ 170$ fescue would provide safer grazing than Ariki ryegrass during a period when facial eczema spore counts are high.

S170 tall fescue thus appears to be a grass capable of playing an important part in the pasture production of many farming areas. Its ability to produce large quantities of palatable feed under conditions of high soil fertility and good management, its resistance to drought and very wet conditions, the high quality of the fodder it produces - all these factors are important.

There is a further point that must be mentioned. A certain amount of seed has been harvested from areas sown down with 5170 fescue in the South Island. L. Anderson, of Grasslands Division, D.S.I.R., Palmerston North, has stated that plants derived from one line of this seed do not perform as well as $\$ 170$ as single-spaced plants at Palmerston North. This being the case, prospective growers should insist in the meantime on getting $\mathrm{S} 170$ seed that has been imported from Britain.

\section{DISCUSSION}

How does S170 fescue perform under continuous und heavy stocking?

We have no knowledge of its performance under continuous stocking. We do know that it must be heavily stocked when it is ready for grazing if it is to produce at a maximum level.

Is there any genetic inheritance variability?

Our observations suggest that the areas of S170 we know are of a fairly uniform type, with a minimum of variability.

Could not management of $S 170$ be tricky in view of the recommendation of grazing at five inches, if growth is as rapid as the speakers describe?

Yes. That is why we stress that this is a grass for the heavily-stocked farm. Its use would not be desirable on an understocked property.

What is the degree of susceptibility to rust?

We have seen no evidence of severe rusting. 
Have the speakers any experience of feeding $S 170$ to sheep?

No. All experience with this grass has been on dairy farms. British workers report that the grass is readily grazed by sheep, which do well on it.

\section{Is the grass difficult to eradicate if it gets out of hand?}

Adequate cultural and chemical methods of control are available.

Since experience in Northern Ireland indicated that $\mathbf{5 1 7 0}$ is slow to establish under grazing, owing to treading, would mowing be preferable to grazing in the first year?

British workers recommend cutting the fescue for hay or silage in the first year. On the other hand, we believe slow establishment is more a matter of unsatisfactory sowing methods or inadequate soil fertility levels, particu. larly a low nitrogen level.

\section{Could details be given of facial eczema spore trappings?}

Spore counts were made during periods when spore counts were high in the Tauranga County. Counts were made on experimental plots with areas of fescue and Ariki ryegrass. Pasture growth was 4 to 5 in. in height.

\section{Should $S 170$ fescue be sown alone or with ryegrass?}

We are still working on this aspect of establishment. We know that too heavy a ryegrass seeding will suppress the slower-establishing fescue. On the other hand, a seeding of $5 \mathrm{lb}$ of Ariki ryegrass per acre may help to fill in the gaps between the fescue drills and aid weed suppression and total herbage production during the first year. We are also exploring the possibility of underseeding established stands of fescue with Ariki, Paroa, or Western Wolths ryegrass. 